BJHS 51(3): 395-422, September 2018. C British Society for the History of Science 2018. This is an Open Access article, distributed under the terms of the Creative Commons Attribution-

NonCommercial-ShareAlike licence (http://creativecommons.org/licenses/by-nc-sa/4.0/), which permits non-commercial re-use, distribution, and reproduction in any medium, provided the same Creative Commons licence is included and the original work is properly cited. The written permission of Cambridge University Press must be obtained for commercial re-use.

doi:10.1017/S0007087418000511

\title{
Illustrating natural history: images, periodicals, and the making of nineteenth-century scientific communities
}

\author{
GEOFFREY BELKNAP*
}

\begin{abstract}
This paper examines how communities of naturalists in mid-nineteenth-century Britain were formed and solidified around the shared practices of public meetings, the publication and reading of periodicals, and the making and printing of images. By focusing on communities of naturalists and the sites of their communication, this article undermines the distinction between amateur and professional scientific practice. Building on the notion of imagined communities, this paper also shows that in some cases the editors and illustrators utilized imagery to construct a specifically British naturalist community. Following three 'amateur' natural-history periodicals (Science Gossip, Midland Naturalist and the Journal of the Quekett Microscopical Club) the article demonstrates how the production and reproduction of natural history in the nineteenth century was contingent on community debate - and that this debate both was highly visual and moved across printed and geographical boundaries. This paper investigates images both for their purported success and for their ascribed value to natural history. Additionally, it considers the debates over their limitations and alleged failures of printing. Altogether, the article argues that investigating the communal practices of observation, writing, drawing and engraving allows for a better understanding of the shared practices of nineteenth-century natural history.
\end{abstract}

\section{Introduction}

A potential nineteenth-century reader for the newly founded natural-history periodical 'the Midland Naturalist (1878-1882)' needed only to turn to its frontispiece to get a sense of what was on offer (Figure 1). The cover image is a panoply of the visual subjects found in this particular natural-history periodical. ${ }^{1}$ Botanical specimens populate the centre-foreground of the image, while vignettes - which encapsulate the broad span of

* National Science and Media Museum, Little Horton Lane, Bradford, BD1 1NQ, UK. Email: geoff. belknap@scienceandmediamuseum.org.uk.

This research was conducted as part of the AHRC-funded project Constructing Scientific Communities: Citizen Science in the Nineteenth and Twenty-First Centuries. I would like to thank Gowan Dawson, Sally Shuttleworth, Matthew Wale, Sally Frampton and Berris Charnley for their comments on this paper, and Paul Cooper and Andrea Hart from the Natural History Museum for finding sources I would have never come across without their guidance. I would also like to thank the community of citizen scientists at www. sciencegossip.org who informed the research for this paper - and in particular 'Jules' and 'Zuzi' for taking the time to read and comment on this article.

1 The illustrated cover page has a long history in scientific printed works - particularly books - from the seventeenth century onwards. See Inga Elmqvist Söderlund, Taking Possession of Astronomy: Frontispieces 


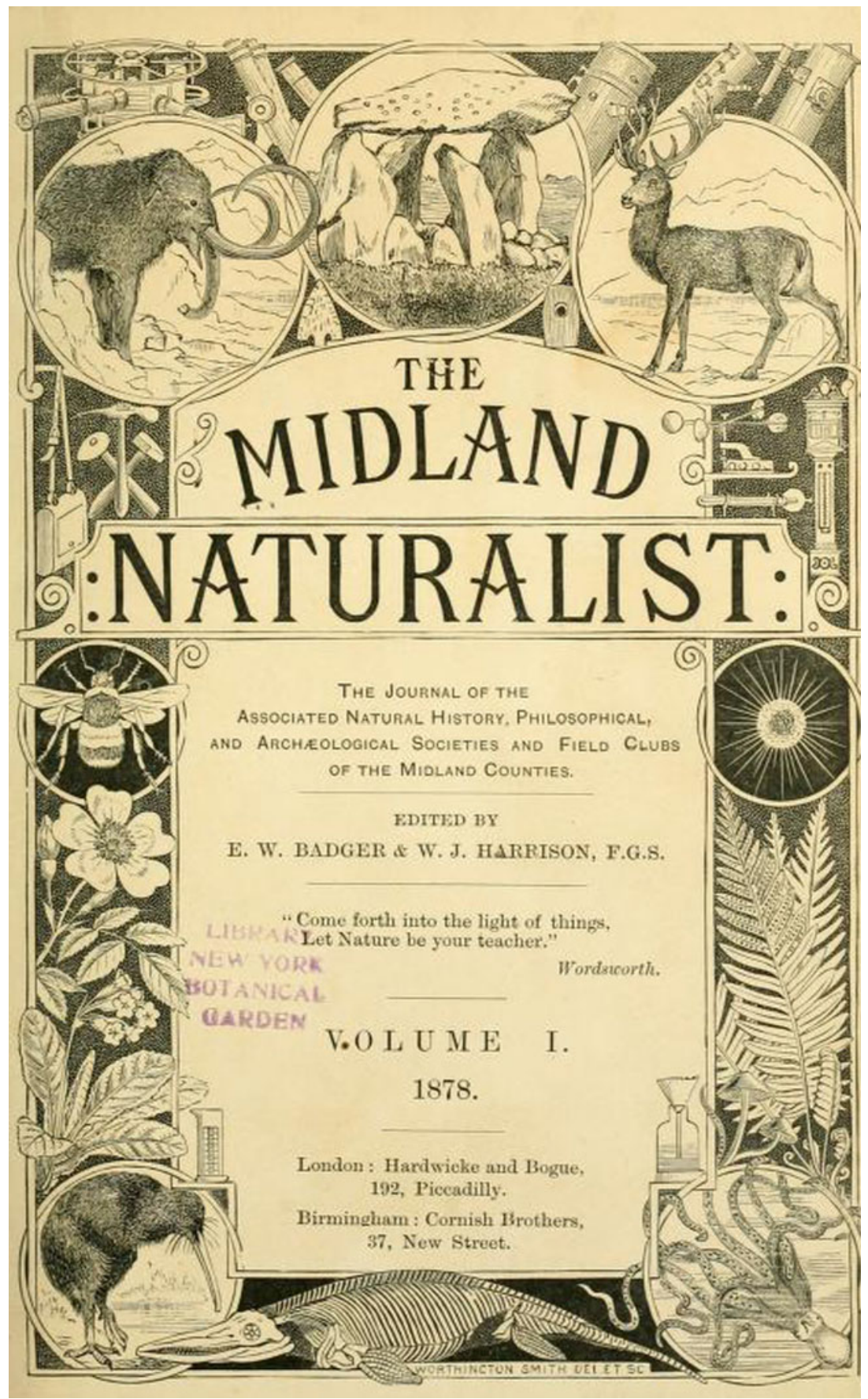

Figure 1. Title page for the Midland Naturalist, including a border illustration drawn and engraved by Worthington George Smith. Midland Naturalist (1878) 1(1), frontispiece. Image from the Biodiversity Heritage Library at www.biodiversitylibrary.org/item/50180\#page/5/ mode/1up. 
natural history - guide the reader around the circumference of the page: from a depiction of a mammoth, to ancient stone monuments, to colonial mammals and objects seen only under the microscope. These vignettes are positioned against a background matrix of instruments of observation, excavation and measurement. At the bottom of the page, punctuating the narrative with its non-corporeal form, is a depiction of an ichthyosaur fossil similar to that found by the Anning siblings sixty years previously in Lyme Regis.

The authorship of this frontispiece, which is inscribed underneath the body of the ichthyosaur, tells an important story about the role of illustrators and illustrations for natural-history publications. 'Worthington [George] Smith Del. et. Sc' (1835-1917) was, as his signature denotes, an artist and engraver, who offered his services to many of the natural-history periodicals of the time. ${ }^{2} \mathrm{He}$ was also a man with a range of scientific interests - from architecture and archaeology to botany and mycology. ${ }^{3}$

The production of images, Smith pointed out, required a developed set of expertise. Describing the making of this frontispiece to readers of the Midland Naturalist, he claimed that

the design [of the frontispiece], (with all its defects,) was drawn direct on the box-wood block, and engraved at once, without a slip, false line, or alteration. Many readers of the 'Midland Naturalist' will probably be self-taught men, who busily follow industrial occupations every week-day. It may therefore interest such readers to know that the writer of these lines never had any teacher either artistic or scientific, other than he always found supplied to him by close observations, careful reading, experience, and constant perseverance. ${ }^{4}$

While Smith demonstrated his expertise here by detailing how he made the engraving 'at once, without a slip, false line, or alteration', this was not a common experience among those seeking to produce images. As this article will show, the production and reproduction of images in natural-history periodicals were fraught with errors, ultimately affecting the value of the observations. Textual justification and explanation, which sought the validation of the reading community, became essential aspects of the images themselves. Moreover, images, as this quotation also demonstrates, were records of observation as well as teaching objects - designed to guide the reader in how to contribute to the production of natural history. ${ }^{5}$

Scientific discourse in the nineteenth century - especially natural history - was becoming increasingly embedded in the periodical marketplace. ${ }^{6}$ The period in which Smith

and Illustrated Title Pages in 17th-Century Books on Astronomy, Stockholm: Center for the History of Science at the Royal Swedish Academy of Sciences, 2011.

2 'Del' and 'Sc' are abbreviations for delineavit ('he/she drew it') and sculpsit ('he/she carved it').

3 James Dyer, 'Smith, Worthington George (1835-1917)', Oxford Dictionary of National Biography, Oxford University Press, 2004, at www.oxforddnb.com/view/article/61962, accessed 3 September 2015.

4 Worthington George Smith, Midland Naturalist (1878) 1(1), p. 25.

5 The notion of a visual practice in the production of science was first formalized in the foundational work of Michael Lynch and Steve Woolgar, Representation in Scientific Practice, Cambridge, MA: The MIT Press, 1990. See also updated discussion in Catelijne Coopsman, Janet Vertesi and Michael Lynch (eds.), Representation in Scientific Practice Revisited, Cambridge, MA: The MIT Press, 2014.

6 See the forthcoming volume Sally Shuttleworth, Gowan Dawson, Bernard Lightman and Jon Topham (eds.), Constructing Scientific Communities: Science Periodicals in Nineteenth-Century Britain, currently under review with the University of Chicago Press. 
and the Midland Naturalist were operating - the late 1870 s - was a high point of print expansion. ${ }^{7}$ Thousands of new periodical titles were produced over the nineteenth century, creating hundreds of thousands of pages of information about every aspect of nineteenth-century culture. ${ }^{8}$ Much of this content was, as this article will show, visual. ${ }^{9}$ Moreover, the visual content of these periodicals was a key tool for the creation and circulation of natural-historical knowledge within a network of practitioners. ${ }^{10}$

This article contends that what it meant to participate in science in the Victorian period was not simply a process of learned observational techniques, nor a belief in an experimental or epistemological process of uncovering natural knowledge. Scientific practice, moreover, was not only a process of reading, going into the field or - later in the century (at least in Britain) - working in a laboratory or institution. Rather, what constituted 'doing' science in the period - and in particular doing natural history - was a mixture of visual, verbal and textual observation, parsed and reconfigured through a set of community-based activities. ${ }^{11}$ The construction of knowledge communities in these periodicals also played a role to borrow from Benedict Anderson - in imagining a British, scientific nation. ${ }^{12}$

7 For a recent and important discussion of the relationship between offprints, periodicals and the production of scientific authorship see Alex Csiszar, 'Broken pieces of fact: the scientific periodical and the politics of search in nineteenth-century France and Britain' (2010), unpublished PhD thesis, Harvard University; and Melinda Baldwin, Making Nature: The History of a Scientific Journal, Chicago: The University of Chicago Press, 2015.

8 For discussions of the nature of specialist journals in the nineteenth century see David E. Allen, 'The struggle for specialist journals: natural history in the British periodicals market in the first half of the nineteenth century', Archives of Natural History (1996) 23(1), pp. 107-123.

9 There have been a few concerted efforts to address illustrations in periodicals by historians of science, media and print such as Brian Maidment, Laurel Brake, Peter Sinnema, Celina Fox and Geoffrey Belknap. Brian Maidment, Reading Popular Prints, 1790-1870, Manchester: Manchester University Press, 1996; Peter Sinnema, Dynamics of the Pictured Page: Representing the Nation in the Illustrated London News, Aldershot: Ashgate, 1998; Celina Fox, Graphic Journalism in England during the 1830s and 1840s, New York: Garland, 1988; Laurel Brake, The Lure of Illustration in the Nineteenth Century: Picture and Press, Basingstoke: Palgrave Macmillan, 2008; Gerry Beegan, The Mass Image: A Social History of Photomechanical Reproduction in Victorian London, Basingstoke: Palgrave Macmillan, 2008; and Geoffrey Belknap, From a Photograph: Authenticity, Science and the Periodical Press, 1870-1890, London: Bloomsbury Academic, 2016.

10 This article follows directly from the work of Anne Secord, who has demonstrated the importance of both images and networks for working-class 'artisan botanists' in the early nineteenth century. Anne Secord, 'Artisan naturalists: science as popular culture in nineteenth-century England' (2002), unpublished PhD thesis, University of London. For the relation to images and botany also see Secord, 'Botany on a plate: pleasure and the power of pictures in promoting early nineteenth-century scientific knowledge', Isis (2002) 34(15), pp. 28-57. For a broader discussion about the making of images for natural history see Charlotte Sleigh, The Paper Zoo: 500 Years of Animals in Art, London: The British Library, 2016.

11 For a discussion of the relationship between natural history and collecting practices see Robert E. Kohler, 'Finders, keepers: collecting science and collecting practice', History of Science (2007) 45(4), pp. 428-454. Recently, scholars such as Ruth Barton and Jim Endersby have also shown that for sciences like natural history, the terms 'professional' and 'amateur' were problematic categories for the late nineteenth century, and that these boundaries were indistinct despite claims by some professionalizers - such as T.H. Huxley to the contrary. See Ruth Barton, “Men of science": language, identity and professionalization in the midVictorian scientific community', History of Science (2003) 41(1), pp. 73-117; and Jim Endersby, Imperial Nature: Joseph Hooker and the Practices of Victorian Science, Chicago: The University of Chicago Press, 2010.

12 While Benedict Anderson usefully theorizes how imagined national communities are constructed through media outlets, such as the periodical and the newspaper, this paper demonstrates that scientific communities particularly those within natural history - were made first in the lecture theatre and the local club or society, 
While communities were made, and partially imagined, through correspondence networks, meetings at learned societies, the circulation of pamphlets and offprints, and the publication of other forms of scholarly communication, it was only the periodical that brought together all these forms of community building into one, serially constructed, textual and visual space. The nineteenth-century scientific periodical is, in this way, a premier and primary site for the construction of science, which, to borrow Robert Darnton's terminology, closes a communication circuit through which scientific knowledge was formalized. ${ }^{13}$

The remainder of this article traces the use of illustrations in three nineteenth-century British natural-history periodicals: Science Gossip (1865-1910), the Journal of the Quekett Microscopical Club (QMJ) (1865-present), and the Midland Naturalist. The choice of these periodicals is not arbitrary; they reflect three seemingly divergent publications with markedly different content and audiences. The first was a catch-all journal for anyone interested in natural history, the second a specialist journal for 'amateur' microscopists, and the third a consortium journal formed around a group of Midlands natural-history societies. The audiences for these periodicals were also different. Science Gossip directed its content towards the broad range of middle-class readers who had an interest in the natural world. The QMJ and the Midland Naturalist, on the other hand, were periodicals directed at a specific audience - the members of the societies that they serviced.

But dig a bit deeper into both the use of images and the make-up of the communities which form these periodicals, and you find three fundamentally linked periodicals, which circulated around a set of individuals who populate the rest of this article. These include the editor, mycologist and artist Mordecai Cubitt Cooke (1825-1914); the artist, engraver and naturalist Worthington George Smith; and the engraver and microscopist George Ruffle (?-1916). At the centre of this network of societies, periodicals and images was the publisher Robert Hardwicke (1822-1875). Like the frontispiece for Midland Naturalist depicted above, the practices of natural history in the nineteenth century gathered together a wide range of subjects, individuals and tools of observation and representation.

\section{Forming periodical communities}

Little is known about the prolific publisher Robert Hardwicke. This gap may be due in part to the fact that no known archive exists for any of his correspondence or manuscripts - which, based on the size of his network and the number of items he published,

and were later expanded and reconstructed in print, thus making them only partially imagined. Benedict Anderson, Imagined Communities: Reflections on the Origin and Spread of Nationalism, London: Verso, 2006.

13 Robert Darnton, 'What is the history of books?', Daedalus (1982) 111(3), pp. 65-83; Darnton, “'What is the history of books?" revisited', Modern Intellectual History (2007) 4(3), pp. 495-508. For a discussion of the 'periodical circuit' also see Will Tattersdill, 'Further northward: polar exploration and the empire in the fact and fiction of the periodical press', Chapter 4 of Tattersdill, Science, Fiction, and the Fin-de-Siecle Periodical Press, Cambridge: Cambridge University Press, 2016, pp. 132-181. 
must have been extensive. ${ }^{14}$ Research on Hardwicke is limited to a short 1986 biography by Mary English and a brief reference to Hardwicke's influence in microscopy in an article by William Brock, published in 1989. ${ }^{15}$ Hardwicke is known to have had connections with the emerging network of influential scientists of the period. In 1863 he published a compilation of T.H. Huxley's working men's lectures - however, this was not a relationship particularly valued by Huxley. ${ }^{16}$ Writing to Charles Darwin in 1862, Huxley described the book in the following terms: 'I was asked to allow them [the working men's lectures] to be taken down in shorthand for the use of the audience but I have no interest in them \& do not desire or intend that they should be widely circulated'. ${ }^{17}$ While Hardwicke may have been viewed by Huxley - and by extension his correspondence network - as a vehicle for publishing unwanted popular work, it was to the 'amateur' societies and individuals that Hardwicke dedicated most of his effort and support, and where he developed a community of active and engaged naturalists. ${ }^{18}$

To create this community required more than printing a periodical. Rather, the periodicals published by Hardwicke developed from a set of pre-existing communities, which included clubhouses, field excursions and scientific societies. According to English, the network which would come to dominate the set of periodicals published by Hardwicke was first established in the meeting rooms of the Society of Amateur Botanists, a club formed by Cooke, and hosted by Hardwicke in the office of his publishing house. The society was centred around a mutual desire for the exchange of specimens

14 Hardwicke published a whole range of books and periodicals between 1850 and his death in 1875, but focused on the medical and natural-history genres. Among many others, he published Popular Science Review (1861-1881), the Journal of Botany, British and Foreign (1863-1879), Hardwicke's Science Gossip (18651910), the Journal of the Quekett Microscopical Club (1868-present) and the Midland Naturalist (18781882). In 1863 alone he published such monographs as T.H. Huxley's On Our Knowledge of the Cause of the Phenomena of Organic Nature, London: Robert Hardwicke, 1863; and Edwin Lankester's Half Hours with the Microscope [1863] and an edited series with coloured plates of James Sowerby's English Botany (1863-1872). He was also a founding member, and financial backer, for two natural-history societies: the Society for Amateur Botanists (1862-1865) and the Quekett Microscopical Club (1865-present).

15 See Mary P. English, 'Robert Hardwicke (1822-1875), publisher of biological and medical books', Archives of Natural History (1986) 13(1), pp. 25-37; and William Brock, 'Patronage and publishing: journals of microscopy 1839-1989', Journal of Microscopy (September 1989) 155(3), pp. 249-266, 253.

16 Huxley, op. cit. (14).

17 Letter no 3841, Darwin Correspondence Project, at www.darwinproject.ac.uk/DCP-LETT-3841, accessed 28 January 2017.

18 This regard for Hardwicke by Huxley did not stop Charles Darwin from reading and writing to Science Gossip in 1867 to discuss hedgehogs. See Letter no 5702, Darwin Correspondence Project, at www. darwinproject.ac.uk/DCP-LETT-5702, accessed 28 January 2017. For the relationship between Huxley and popular print culture see Gowan Dawson, Show Me the Bone: Reconstructing Prehistoric Monsters in Nineteenth-Century Britain and America, Chicago: The University of Chicago Press, 2016, Chapter 7, 'The problems with popularization'. For a discussion of the influence of the X-Club - a dining club which would go on to support more dominant periodicals such as Nature-see Ruth Barton, "An influential set of chaps": the X-Club and Royal Society politics 1864-85', BJHS (1990) 23(1), pp. 53-81; and Barton, 'Scientific authority and scientific controversy in Nature: north Britain against the X Club', in Geoffrey Cantor, Gowan Dawson, Richard Noakes, Sally Shuttleworth and Jonathan R. Topham (eds.), Culture and Science in Nineteenth-Century Media, Aldershot: Ashgate, 2004, pp. 223-235. 
and the organization of excursions into the field. ${ }^{19}$ The individuals who first came to these meetings included Hardwicke, Mordecai Cubitt Cooke, Worthington Smith and George William Ruffle. Each of them became enmeshed in a community which was formed within the boundaries of a scientific society, but soon expanded to a dispersed community, connected by the reproduction of images and texts that were bound within the weekly, monthly or annual periodicals. ${ }^{20}$

Between society meetings and the pages of the illustrated periodical, this community of naturalists was able to help reinforce the sites and practices of natural history during the second half of the nineteenth century. Within this network, Hardwicke acted as an essential facilitator, rather than keen observer or illustrator; he enabled the community's existence through his support of societies and his establishment of periodicals. ${ }^{21}$ Yet when the dynamics of the community shifted, they were reconstituted in a new periodical or society. As this article will show, the production and printing of illustrations in these various natural-history communities played a critical role in constructing scientific practice.

\section{Hardwicke’s Science Gossip}

In 1865 Cooke, Hardwicke and other members of the Society of Amateur Naturalists felt that there was a gap in the periodical marketplace. To address this, Hardwicke took it upon himself to launch his own monthly journal dedicated to all topics of natural history, richly illustrated, written in engaging and plain language and priced at an affordable fourpence an issue. The journal was to straddle the boundaries between the 'amateur' and the 'expert', between science and gossip. It was aptly named Science Gossip and ran for forty-five years before it was absorbed by a rival at the end of the first decade of the twentieth century. ${ }^{22}$

The first editor of Science Gossip was Hardwicke's recent acquaintance, Mordecai Cubitt Cooke. For Hardwicke, Cooke was a logical choice-he was an established mycologist who had already published a number of popular and generalist works on British botany and fungi with Hardwicke in the early 1860s. He was perfectly suited to edit Science Gossip, which positioned itself as a journal that incorporated the increasingly divided worlds of the amateur and professional naturalist. In the words of its second editor, John Ellor Taylor, Science Gossip

19 Mary P. English, Mordecai Cubitt Cooke: Victorian Naturalist, Mycologist, Teacher and Eccentric, Bristol: Biopress, 1987, pp. 96-97. For a description of the Society for Amateur Botanists see John Ramsbottom, 'The President's Address: the Society of Amateur Botanists and the Quekett Microscopical Club', Journal of the Quekett Microscopical Club, series 2 (20 September 1932) 16(98), pp. 214-230.

20 For a recent discussion of the relationship between society meetings and periodicals, focusing on the Royal Society, see Aileen Fyfe and Noah Moxham, 'Making public ahead of print: meetings and publications at the Royal Society, 1752-1892', Notes and Records: The Royal Society Journal of the History of Science (2016) 70(4), pp. 361-379.

21 In this article an actor or node in the network is both human and non-human. Nodes are sometimes images, sometimes texts, sometimes collections of people in a place, whether physical or literary. As such, this article seeks to avoid using any terminology explicitly adopted by actor-network theory. Bruno Latour, Reassembling the Social: An Introduction to Actor-Network Theory, Oxford: Oxford University Press, 2005.

22 Science Gossip ran as a consecutive title between 1865 and 1893, was reconfigured between 1894 and 1902, and was finally absorbed into Knowledge in 1910. 
stand[s] between the High Priests of pure science and the humbler votaries who would know its wisdom. Our ambition is not to be esteemed learned, so much as to be deemed useful. By uniting in monthly fellowship the unassuming but ardent lovers of nature, we feel we are doing much good; by giving them the means of noting phenomena worth notice, comparing notes, and in relieving each other's difficulties, we are helping on that reign of 'Good-will towards men'. 23

The aim not to be 'esteemed learned' was a sideways stab at the journals produced by the 'learned societies' which dominated established scientific practice and prestige of the late nineteenth century. ${ }^{24}$ Science Gossip, in contrast to its learned counterparts, existed to establish a community - a 'monthly fellowship' for all naturalists. It was a place where the pages of the periodical offered a stable site for exchanging information. What Taylor neglects to point out, however, is that much of this information was constructed in visual terms.

Science Gossip was a journal dominated by visual images. Over a fifteen-year period between 1865 and 1880, it published 4,187 images. Considering that within this period Science Gossip printed 4,264 pages, this meant that, on average, there was almost one image on each page. In other words, images were a dominant aspect of the content and reading experience of this periodical.

The distribution of total counted illustrations and total counted plates across the years can be found in Figure 2. The solid line represents the total number of illustrations as calculated by the author; the dashed line denotes the number of times images were grouped together (plates). What is particularly interesting is that while this graph visualizes the relative importance of illustrations to the production of Science Gossip, it also gives a clear indication of the degree to which changes in editors had an effect on its publication. The sharp drop between volumes seven and eight occurred when, on Hardwick's instruction, the geologist John Ellor Taylor replaced Cooke as editor. While the number of published pages within Science Gossip remained the same under Taylor, there was a distinct reduction in the number of illustrations. This indicates a difference in editorial preference towards illustrations for the communication of scientific knowledge.

The replacement of Cooke by Taylor warrants further discussion as the reasons behind this transition tell us something about how relationships, and communities both scientific and publishing-based ones-could change quickly. According to Smith-who wrote Cooke's obituary in 1914 in the periodical Gardener's Chronicle - a rift between Hardwicke and Cooke developed when Cooke decided to publish his first major popular work on mycology with the well-established scientific

23 John Ellor Taylor, 'Preface', Science Gossip (1872) 8, n.p.

24 For a discussion of the most prestigious of these learned societies - the Royal Society - see the special issue of Notes and Records of the Royal Society (2015) 69(3). In particular see the introduction by Aileen Fyfe, Julie McDougall-Waters and Noah Moxham, '350 years of scientific publishing', Notes and Records of the Royal Society (2015) 69(3), pp. 227-239; and Aileen Fyfe, 'Journals, learned societies and money: Philosophical Transactions, ca. 1750-1900', Notes and Records of the Royal Society (2015) 69(3), pp. 277-299. 


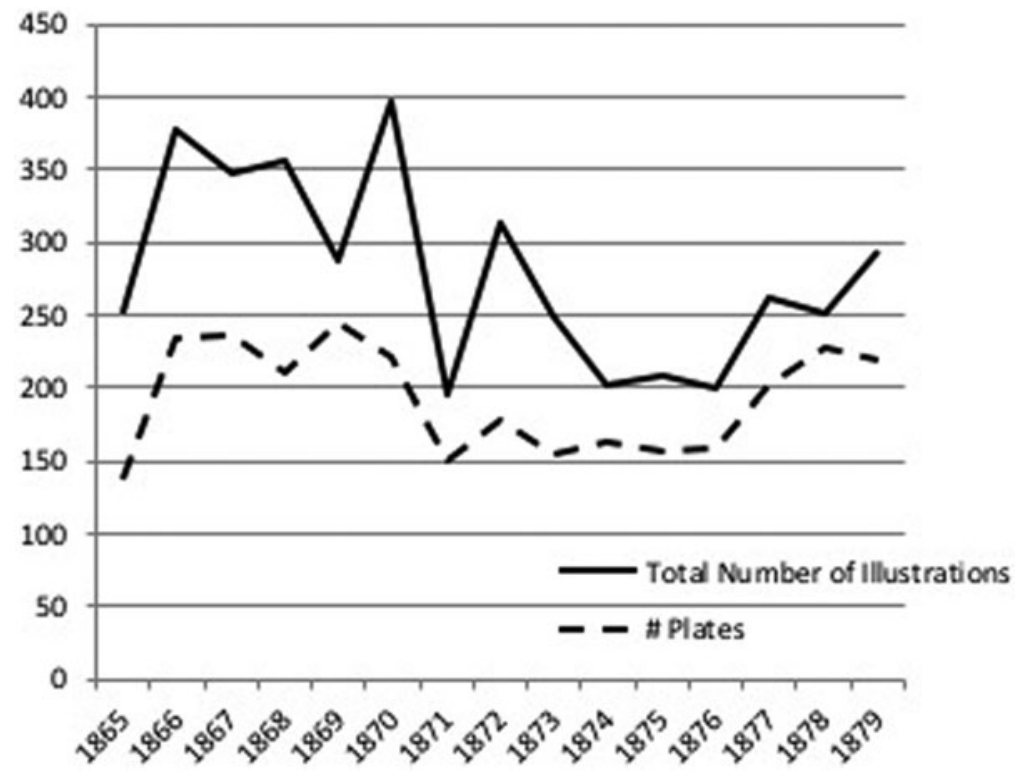

Figure 2. Number of illustrations and plates reproduced in Science Gossip between 1865 and 1880. Source: the author.

publisher Macmillan in 1871, rather than with Hardwicke. ${ }^{25}$ Seemingly in response to this professional insult, Hardwicke quickly replaced Cooke as the editor of Science Gossip. Due to this rift, this core group - which was first established in the Society of Amateur Botanists - reached a crisis point. Yet such networks, which crossed community forums and included a diverse range of participants, were not easily dissolved. The relationship between Cooke and Smith, for example, was not just a personal friendship, but also articulated through the periodical, with the tip of the engraver's burin as its primary medium.

Smith sustained himself and his family primarily by working as an illustrator and engraver, offering his services to many of the natural-history periodicals of the mid-nineteenth century. He was the chief illustrator for the popular periodical Gardeners' Chronicle, and was a regular contributor to Science Gossip and the Midland Naturalist. ${ }^{26} \mathrm{He}$ was an author, illustrator and engraver, and in this way moved between the boundaries of the visual and the textual practices of Victorian natural history.

After leaving his position as an architectural apprentice with Horace Jones in 1861, Smith took his pen and burin and started to apply them to botanical illustration. ${ }^{27}$

25 W.G. Smith, The Gardiners' Chronicle (28 November 1914) 56, pp. 356-357. The book in question was Mordecai Cubitt Cooke, Handbook of British Fungi: With Full Descriptions of All the Species, and Illustrations of the Genera, London and New York: Macmillan and Co., 1871. See English, op. cit. (19), p. 134.

26 Dyer, op. cit. (3).

27 James Dyer, 'Worthington George Smith', Bedfordshire Historical Record Society (1978) 57, p. 143. 
His first illustrated journal article appeared in the Journal of Horticulture, Cottage Gardener and Country Gentleman (1848-1915), edited by the two well-known horticulturalists George Johnson and Robert Hogg. Smith's first images consisted of two three-quarter-page plates displaying various aspects of the plant Cephalotaxus (Figure 3). Smith's plates are rich in detail and finely reproduced. The plant depicted in this plate-Cephalotaxus fortunei, a Chinese variety of a plum yew shrub-is laid out on the page in the same way that a naturalist would construct a herbarium sheet. Herbarium sheets were the traditional method for preserving a record of plant specimens, where a sample of the stem and the leaves of a plant were taped or glued to a piece of paper before being pressed and preserved alongside other similar sheets. The goal of a herbarium sheet - and of this engraving by Smith - was to give a sense of the visual structure of the plant, as well as to isolate and depict the male and female aspects of the plants (see Figures 2-4 in Figure 3). This latter step was the key to placing the plant within the Linnaean taxonomical system, which was the most widely applied classification system within nineteenth-century British natural history. ${ }^{28}$ Clearly reflecting the organized knowledge of the herbarium sheet, Smith's plate was intended to be a printed simulacrum of the same.

The editors of the Journal of Horticulture, however, did not agree as to the value of Smith's images:

Excellent as our figures are, they necessarily convey a very inadequate idea of the fine effect produced by the great profusion of beautiful drupes with which the branches are literally studded, and we can quite conceive what the appearance of a tree described by Mr. Pince must be. ${ }^{29}$

The images were a failure, according to Johnson and Hogg, because they did not depict the female organ of the plant - the fruit or drupes - with sufficient verisimilitude. While the editors were happy to reproduce the 'inadequate' images of Smith, they also preferred to rely on the words of the observer, Mr Pince. While the Journal of Horticulture would print a lecture Smith gave to the Society of Amateur Botanists a year later, this was the last time that he would send illustrations to this journal, and also the last time that he would produce images for articles not attached to his own name. ${ }^{30}$

Smith's next journalistic attempt resulted in his becoming enmeshed in a network that would prove very fruitful for the remainder of his life. In July 1864, Smith would send a note containing 'Some remarks on the flowers of Euphorbia amygdaloides' to the Journal of Botany, British and Foreign. ${ }^{31}$ The image reproduced for this journal was markedly different from that in the Journal of Horticulture, operating much more as a line drawing, with little shading and tonal detail, but accompanied by a long description of the figure detailing the parts of the flower section. More than anything, this article

28 Paul Lawrence Farber, Finding Order in Nature: The Naturalist Tradition from Linnaeus to E.O. Wilson, Baltimore: Johns Hopkins University Press, 2000.

29 Robert Pince, 'Cephalotaxus fortunei and Cephalotaxus drupacea', Journal of Horticulture, Cottage Gardener and Country Gentleman (8 December 1863) 5, p. 455.

30 Dyer, op. cit. (27), p. 146.

31 Worthington George Smith, 'Some remarks on the flowers of Euphorbia amygdaloides', Journal of Botany, British and Foreign (1864) 7(2), pp. 196-199. The illustration in this article is on p. 198. 


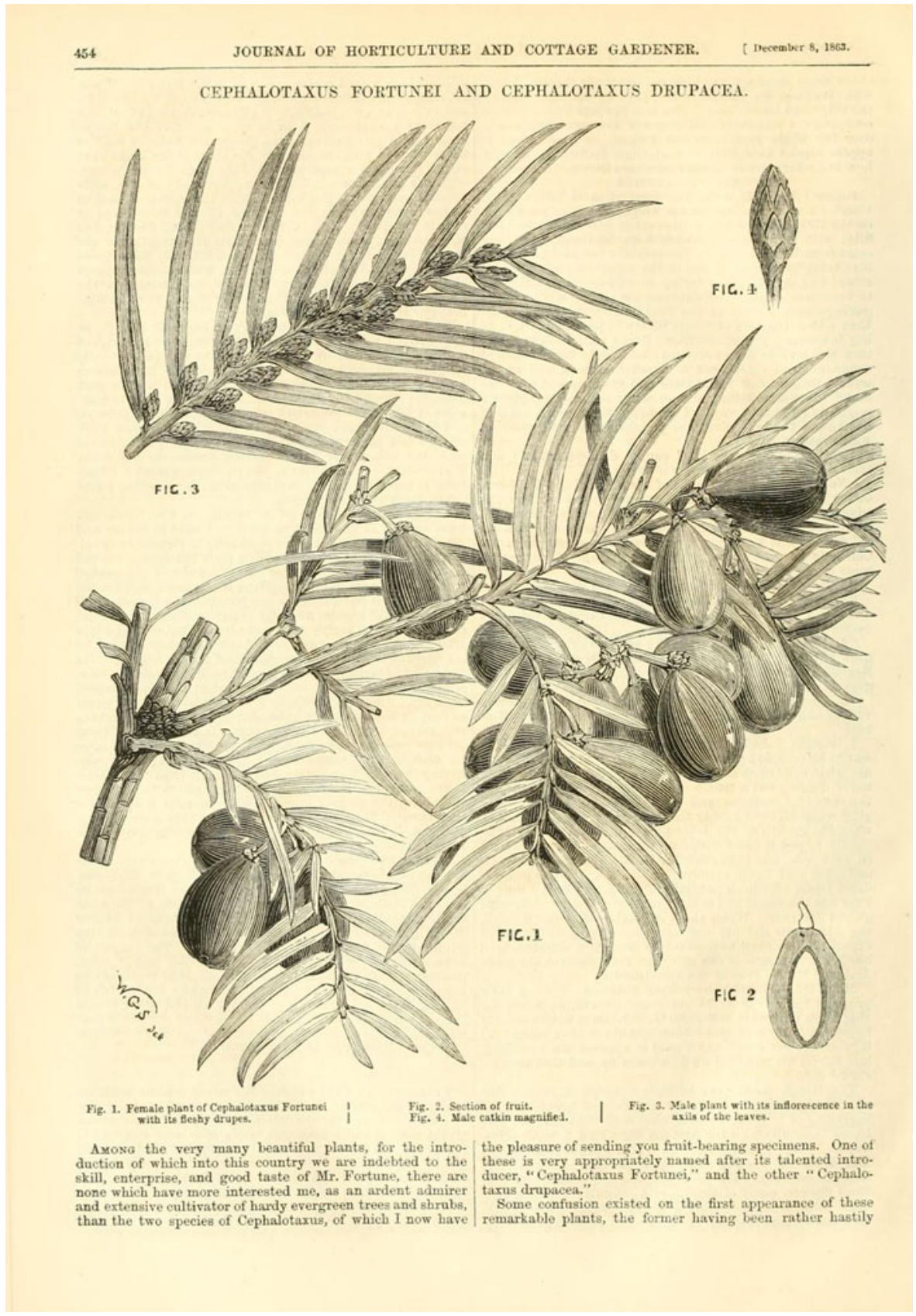

Figure 3. One of two plates of original drawings made by Worthington George Smith for Robert Pince's article 'Cephalotaxus fortunei and Cephalotaxus drupacea' in the Journal of Horticulture, Cottage Gardener and Country Gentleman, new series (8 December 1863) 5(141), p. 454. Image from the Biodiversity Heritage Library at www.biodiversitylibrary.org/item/37143\#page/468/ mode/1up. 
denotes Smith's early publishing relationship with Hardwicke and Cooke - a relationship which had previously been established at the Society of Amateur Botanists in 1863. This relationship - in person and in print - would become useful when Cooke and Hardwicke established their new natural-history journal Science Gossip a year later.

Smith's value as a naturalist and illustrator was utilized by Cooke and Hardwicke from the very inception of Science Gossip. Smith was given the task of designing the border illustration for the title page of the journal (Figure 4). This was no small task, as this pastiche of images needed both to be eye-catching to potential readers, and to epitomize the detail of what constituted natural history in the period. The visual narrative that Smith constructed in this frontispiece would form the basis for his later frontispiece for the Midland Naturalist (Figure 1). The background of the border illustration includes depictions of both the subjects and tools of natural history, and a series of vignettes spaced around the page highlights the animal species observable in Britain during different seasons. Like Figure 1, the pastiche of images is supposed to inform the reader as to the content of the periodical.

For Smith, this task of creating a visual guide for Science Gossip was complicated by the fact that he had to contend with Hardwicke's expectations alongside the vicissitudes of printing accuracy of the period. Reflecting on this illustration in Cooke's obituary, cited previously, Smith wrote,

I was asked to submit a design on paper for the cover. In this I introduced an eagle crouching on a rock, at the top centre; but Mr. Hardwicke would not have an eagle, because, he said, an eagle was not a British bird. 'Why not have an owl?' said he. 'Everyone knows that an owl is British'. And the owl was substituted. At last the block was drawn, approved by all, and engraved. On the publication of the first number someone wrote and pointed out that the shells at the bottom were twisted the wrong way. I had drawn them correctly on the block, but, of course, they were reversed in printing, and so became wrong. ${ }^{32}$

This reflection by Smith is interesting for a number of reasons. It points to the implications of the periodical as a tool for promoting a national identity. Hardwicke's assertion that the frontispiece should have an explicitly British owl, rather than the American eagle, highlights the significance of the periodical in creating the imagined communities posited by Benedict Anderson. ${ }^{33}$ However, unlike the communities formed around periodicals described by Anderson, the ones formed in Science Gossip, the QMJ and the Midland Naturalist were not exclusively imagined, but were communities which first knew each other outside the periodical, through their natural-history society meetings and correspondence networks. Unlike Anderson's communities, they constructed the boundaries of the nation not only through text, but also through the production of image.

The passage quoted above also highlights the degree to which Figure 4 was a communally constructed object, having to pass through many eyes and expectations, and to face the problems of the printers. The reproduction of an image within a periodical, as this passage demonstrates, was prone to errors, which were out of the original artist's

32 Smith, op. cit. (25), pp. 356-357.

33 Anderson, op. cit. (12). Also see the chapter 'Native' in Sleigh, op. cit. (10), pp. 115-172. 


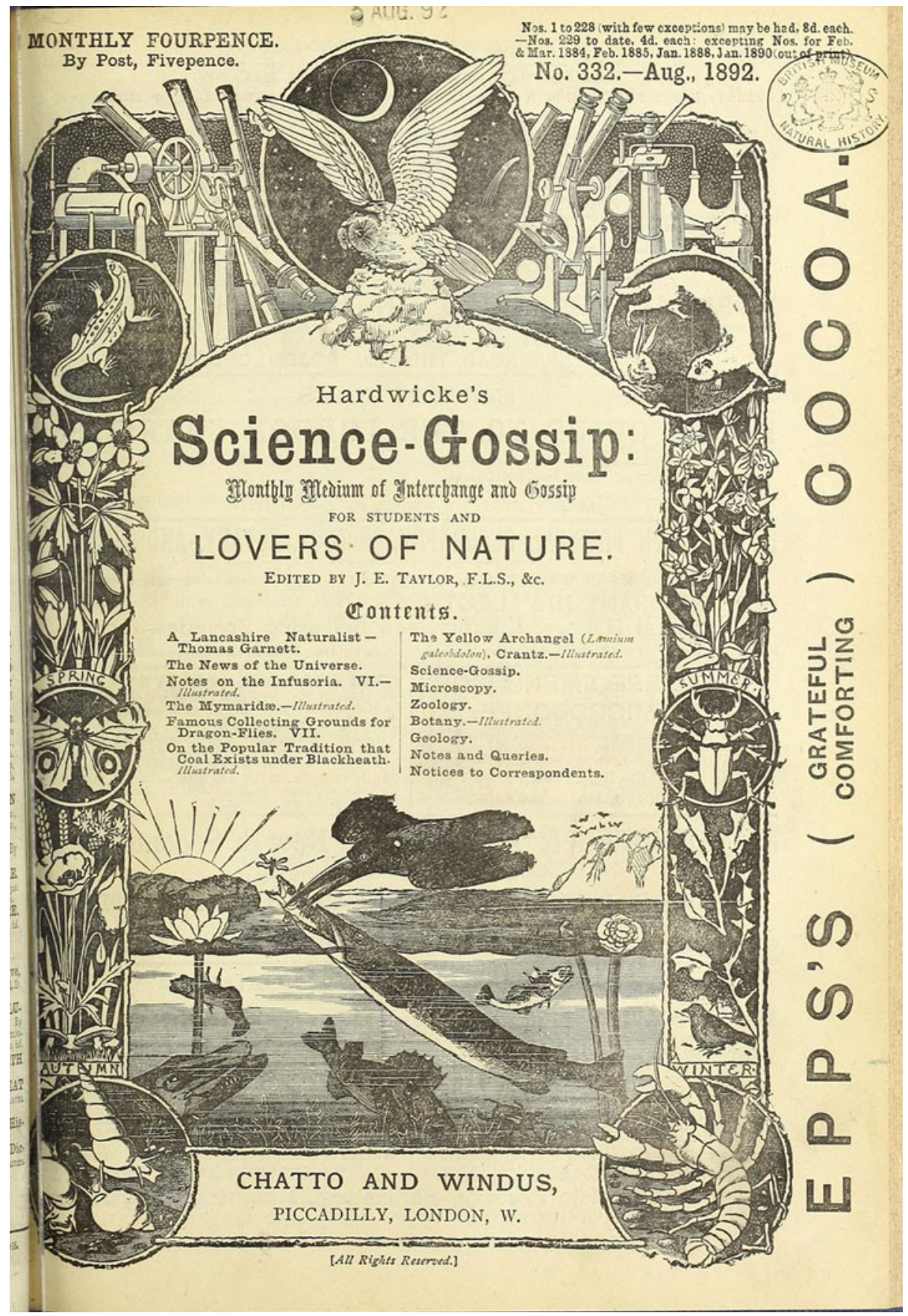

Figure 4. Title page for Science Gossip, including a border illustration drawn by Worthington George Smith. Science Gossip (1892) 28(332), frontispiece. Image from the Biodiversity Heritage Library at www.biodiversitylibrary.org/page/44012222\#page/355/mode/1up. 
hands. Smith, who would have been aware of the pitfalls of wood engraving due to his role as artist and engraver, was nevertheless blamed for the image's inaccuracies. The printer, acting as the middleman, was invisible in this instance, and it was to Smith as the delineator of the original drawing that the question of the image's veracity was put. The engraved image in the periodical is thus one which claims authorship in numerous different ways. The question of who was to be given credit for the image, or blamed for its failure, was constantly shifting. If Smith had been both the artist and the engraver for this illustration, he could have avoided the error.

The network first established by Hardwicke, situated in his offices where he offered free space for the Society of Amateur Botanists, was made concrete in the pages of Science Gossip. After utilizing Cooke's expertise to buoy the journal's credibility, and Smith's to engrave the frontispiece, Hardwicke also needed a reliable, jobbing engraver for illustrations sent in by contributors. George Ruffle became the engraver of choice, who - unlike Smith - contributed to the journal solely as an engraver and not as an observing naturalist.

Over the fifteen-year sample period, Science Gossip published 2,683 articles, 809 of which were accompanied by one or more illustrations. In those illustrated articles where the images were attributed, Ruffle was by far the most regular engraver. In fact, within the images reproduced in Science Gossip, Smith was the only artist and engraver given credit for original visual content. All other images either had no authorship indicated in the image, or were reproduced from other sources. However, given that Smith was both an engraver and an illustrator, it is unclear in which instances he produced the original drawing alone and where he also made the engraving. Accepting these caveats, Ruffle is in fact the only individual within this period of Science Gossip who was given credit for his work in the production of original engravings.

In the more than 150 articles for which Ruffle was engaged as an engraver, the authenticity of his images was never questioned by Science Gossip's editors. Yet this was not always the case for the original artists who contributed the images. In one instance a contributor, who labelled himself or herself R.H.N.B., published an article which included thirty-five purportedly original drawings illustrating various 'Vegetable hairs'. Cooke, as editor, only became aware - after he had committed the money to engraving the images - that they were not, in fact, original drawings. To address this, Cooke added the following postscript to the article:

The Figures illustrating this paper have been engraved facsimile from the writer's sketches. It was not until they were engraved that we discovered the majority of them to be indifferent copies, on an enlarged scale, from the Rev. J.G. Wood's 'Common Objects for the Microscope'. For this plagiarism, therefore, we trust that our readers will hold the author, and not the editor, responsible. - Ed. ${ }^{34}$

Cooke was quick to point out that the responsibility for this instance of plagiarism fell with the author of the images rather than with the engravers or printers. Indeed, he was keen to explain that the engravings - which were described as 'facsimiles' - were not the

34 Mordecai Cubitt Cooke, Science Gossip (1 May 1868) 4(41), p. 104. 
problem. Rather, it was the audacity of the author in copying images directly from a very popular book on microscopy by John George Wood that made the images problematic. ${ }^{35}$

It is useful to note that R.H.N.B. was publishing in Science Gossip with partial anonymity. While some individuals reading his or her articles may have known what these initials stood for, many readers - especially those without intimate knowledge of the community - would not have. It was not until 1873 that the author identified himself as Robert Henry Nisbett Browne. ${ }^{36}$ The role of author in these articles therefore becomes particularly confused, especially regarding the question of originality and authenticity in the publication of images.

For Science Gossip, and for Cooke in particular, image reliability was paramount, especially when reproducing images made with a microscope. Microscopic images relied on the trust of the artist and microscopists. Unless a reader had their own microscope and experience in using it, these images could not be verified. ${ }^{37}$ As such, when Cooke published an article on 'Hairs of Indian bats', including thirty-four engraved illustrations, he was sure to add a note stating that the 'figures illustrating this paper were drawn on wood from slides by Mr. H.F. Hailes, and confirm, independently, the views of the writer'. ${ }^{38}$ The independent observer, cited by Cooke, was Henry F. Hailes, the current editor of the Journal of the Quekett Microscopical Club, a society and journal - as we will see - established by Hardwicke, Cooke and Ruffle. In supporting his claim to producing authentic images of bat hairs, Cooke was not only invoking the authority of multiple observers, but also utilizing his network across various scientific communication venues.

Ruffle's position within Science Gossip was not that of an invisible technician, the fundamental behind-the-scenes worker who, in Steven Shapin's discussion of seventeenth-century scientific practice, made experimental knowledge possible. ${ }^{39}$ Indeed, by inscribing his initials underneath his work, he made himself explicitly visible. While Ruffle's name may not have appeared in the main text of Science Gossip, once you take illustrations and engravings into account, his contribution to the production of natural-history knowledge becomes apparent. Ruffle's position, as a long-standing member of Hardwicke, Cooke and Smith's mobile community, was predicated on his expertise in engraving images. To produce credible visual information required more

35 See John George Wood, Common Objects of the Microscope, London: George Routledge and Sons, 1861.

36 Nisbett Browne did not identify himself in Science Gossip until he published an article on the 'Comparative size of animal hairs', Science Gossip (5 May 1871) 9(101), pp. 108-110.

37 Daston and Galison, in their seminal book on 'objectivity', trace a shift in the nineteenth century where scientifically valid images became dependent on 'mechanical objectivity' rather than co-produced images made with 'four-eye sight' (the collaboration of artist and observer). In this example from Science Gossip, 'objective' images depended on the observer, the artist and the engraver, and the reader's own expertise and access to microscopic technology. Lorraine Daston and Peter Galison, Objectivity, New York: Zone Books, 2007.

38 Mordecai Cubitt Cooke, Science Gossip (1 February 1868) 4(38), p. 31.

39 See Steven Shapin, A Social History of Truth: Civility and Science in Seventeenth-Century England, Chicago: The University of Chicago Press, 1995, in particular Chapter 8, 'Invisible technicians: masters, servants, and the making of experimental knowledge'. 
than an expert observer, artist or engraver, but also details on how this information was packaged and reproduced.

The degree to which Ruffle was given a privileged position in Science Gossip is particularly evident when examining how images from Science Gossip were translated from their original drawing to their final engraving. Figure 5, for example, shows two engravings made by Ruffle for Science Gossip, which depict a 'flag dwelling' found in County Clare, Ireland, by the antiquarian G.H. Kinahan. On further investigation, the only inscription of visual authorship to be found - on the bottom right-hand corner - is that of G. Ruffle. ${ }^{40}$ As these images were printed alongside a series of articles written by Kinahan, a reader might assume that the image's original artist was Kinahan himself. Yet primary ownership of the illustration was granted to Ruffle.

In contrast, the original drawings submitted to Science Gossip for engraving tell a different story. In the original image, diagonally on the bottom left-hand corner, the artist has signed his name, 'E.J. Hardman del' (Figure 6). The erasure of Hardman's name by Ruffle is telling. He was not a regular contributor to Science Gossip, and thus did not need to be acknowledged as the author. Moreover, unlike the plagiarism case with R.H.N.B and John George Wood, Hardman was not an established artist who had the credibility of other publications under his name. The Science Gossip community could be both inclusive and exclusive - and one's status was dependent on both one's personal relationship with the editor and publisher, and one's position within the wider publishing community.

\section{The Journal of the Quekett Microscopical Club (QMJ)}

If Science Gossip was a journal that was developed from the meeting room of the Society of Amateur Botanists, then the Quekett Microscopical Club was a community developed out of the pages of the periodical. Four months after Science Gossip was launched, W. Gibson - who had never published, nor would ever publish, an article or illustration in Science Gossip - wrote a letter to the journal proposing the establishment of a society of amateur microscopists. This society, Gibson argued, could act in contradistinction to the more elitist Royal Microscopical Society (RMS). The RMS had begun as an amateur microscopist society initially named the London Microscopical Society in 1836, but by the time that Gibson was writing it was about to gain a royal charter. This new name change for the society also came with a new definition of who counted as a practitioner of microscopical science, to the exclusion of 'amateur microscopists'.$^{41}$ Gibson, on the other hand, wanted a society which would be open to everyone. He wanted a new microscopical society which would

40 G.H. Kinahan, 'Sketches in the west of Ireland. Chapter V: antiquities of the Burren', Science Gossip (1 April 1875) 11(124), pp. 83-86, 84.

41 See G.L'E. Turner, The Great Age of the Microscope: The Collection of the Royal Microscopical Society through 150 Years, Bristol: Hilger Press, 1989. 


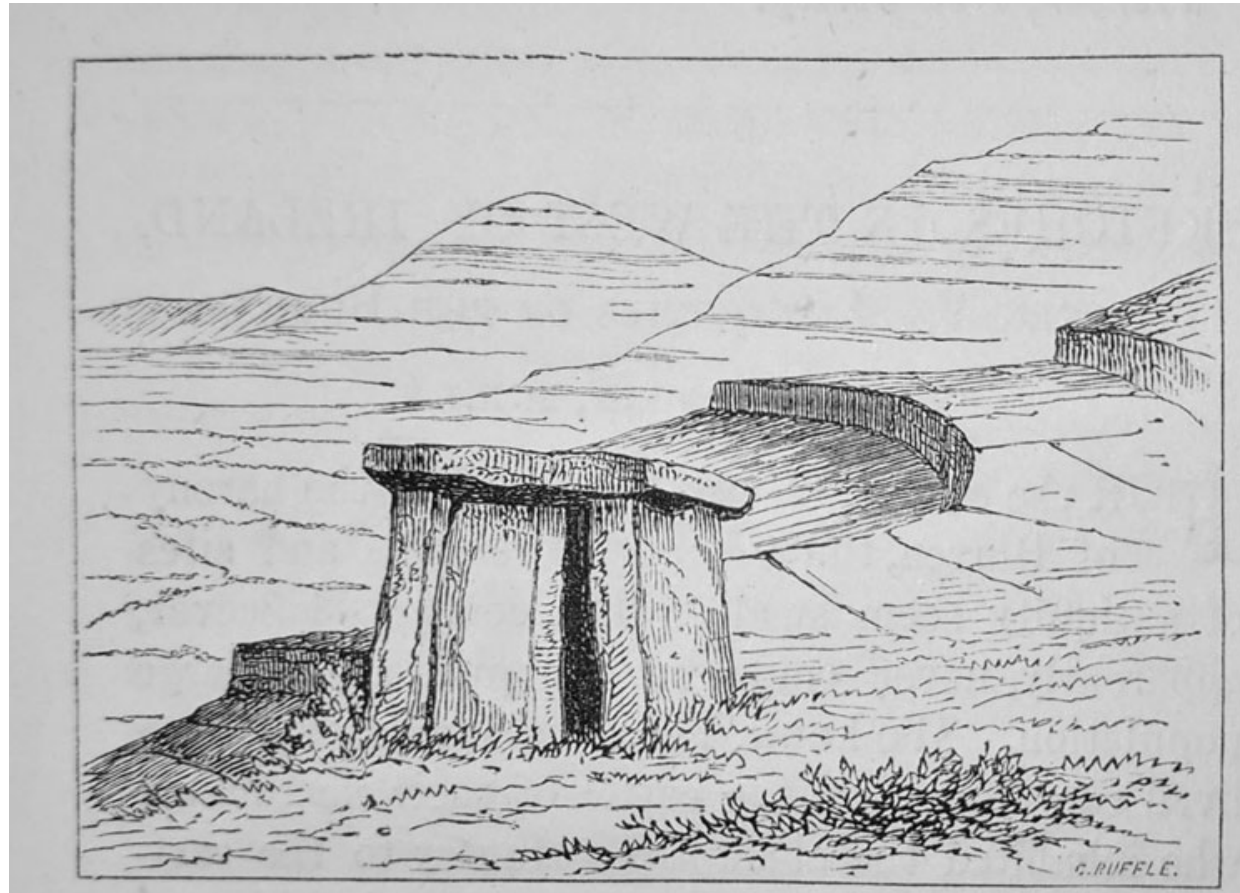

Fig. 54. Fosleac, or Flag-dwelling, Burren, co. Clare.

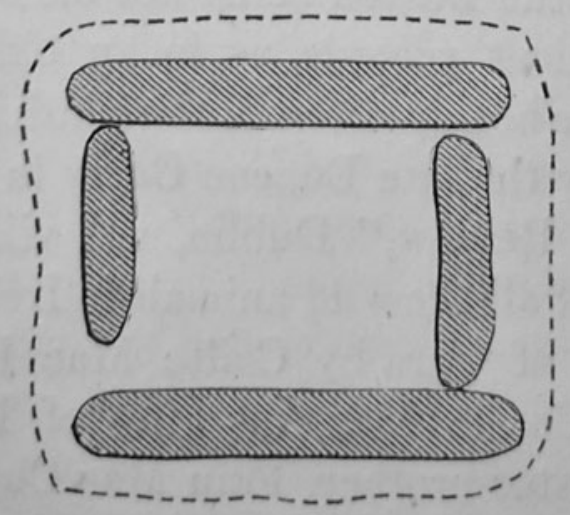

Fig. 55. Plan of ditto.

Figure 5. Figures 54 and 55 from G.H. Kinahan's Science Gossip article 'Sketches in the west of Ireland', Science Gossip (4 January 1875) 11(124), p. 84. () The Trustees of the Natural History Museum, London. 


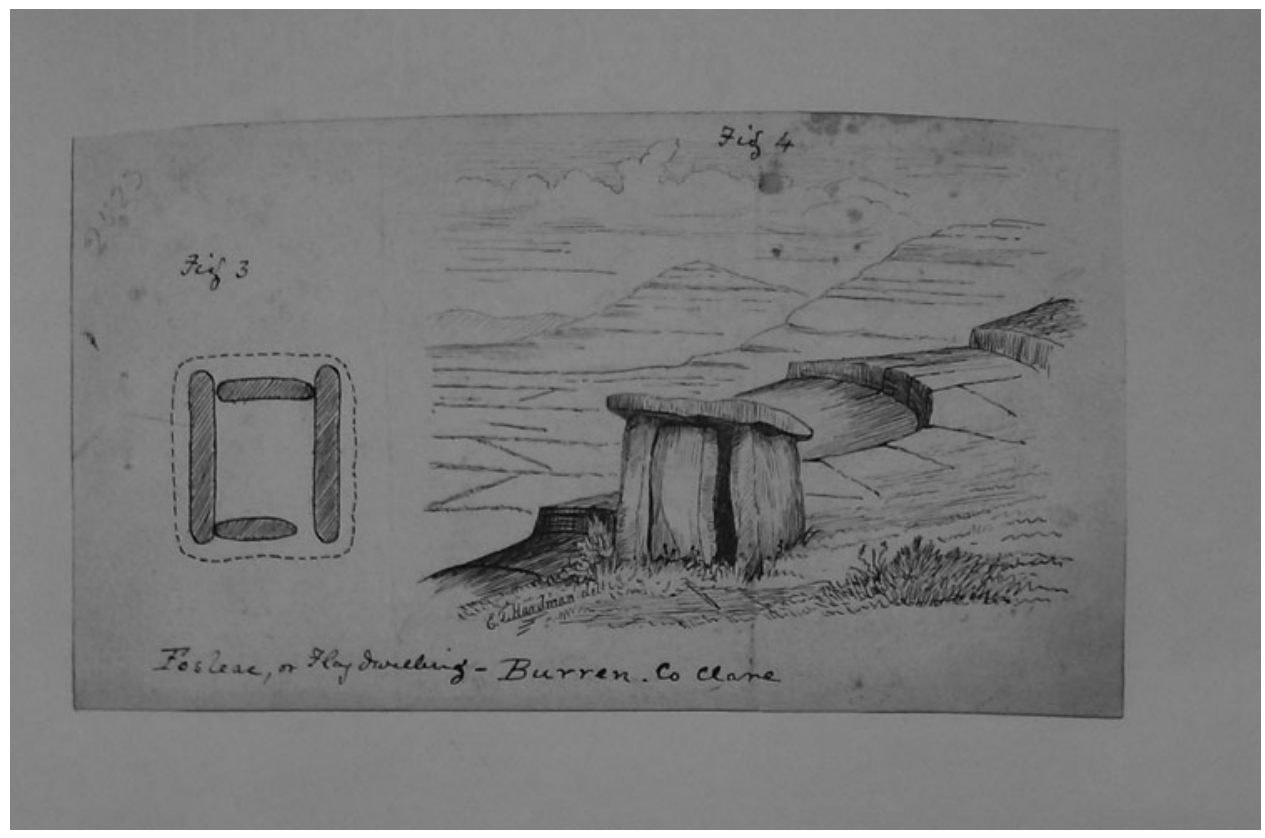

Figure 6. Original drawings made by E.J. Hardmann for G.H. Kinahan's Science Gossip article 'Sketches in the west of Ireland'. The volume of drawings is titled 'Original sketches and photographs used as sources for the illustrations published in Science Gossip c1865-1900' and is held in the Library and Archives, Natural History Museum, London. () The Trustees of the Natural History Museum, London.

give amateurs the opportunity of assisting each other as members of an amateur-society, with less pretension, holding monthly meetings in some central locality, at an annual charge sufficient to cover the incidental expenses - say five shillings a year - on the plan of the Society of Amateur Botanists. ${ }^{42}$

Like the Society of Amateur Botanists - out of which emerged the network of Hardwicke, Cooke, Smith and Ruffle - Gibson wanted a specialist society which could improve the maligned position of the 'amateur' microscopist. A month and a half later, the Quekett Microscopical Club (QMC) held its first meeting. ${ }^{43}$ However, the community which came to establish the QMC was far from amateur, in both the scientific and the publishing worlds. The society's founding members included individuals such as Gibson, alongside two other unknown amateurs, T. Kettingham and E. Marks. Other members included Hardwicke (who was incidentally also a fellow of the Linnean Society); Cooke; Ruffle; Henry F. Hailes, who - as we saw earlier - was a trusted microscopist and later editor; Witham Bywater and Edward Jacques, who

42 W. Gibson, 'Proposal to London microscopists', Science Gossip (1 May 1865) 1(4), p. 116.

43 The society was named after the recently deceased John Thomas Quekett (1815-1861), the pioneering histologist, microscopist and conservator under Richard Owen at the Huntarian Museum of the Royal College of Surgeons. 
were both members of the Royal Microscopical Society; and S. Highley, a fellow of the Geographical Society. When it came to nominating the society directors in the following month, it was these latter members - who had pre-established affiliations and connections - who were given positions of authority. Hardwicke became society treasurer and publisher of the QMJ, Cooke the foreign-correspondence director, Ruffle the microscope slide curator, Jacques the librarian and Bywater the vice president.

The first president, Edwin Lankester, was a member of the society, but never presented any of his findings either during meetings or in the journal. Rather, he acted primarily as a figurehead seeking to establish the prestige of the society. The affiliation with Lankester may have come about due to his position as a very well-known public-health reformer and naturalist, being also a fellow of the Royal and Linnaean Societies. In fact, at the end of Lankester's tenure as president in 1866, the committee minute books of the QMC reflected that

[n]o small amount of our success has been due to the influence of our President. Ever foremost in any movement having for its object the advancement of Popular Science, Dr. Lankester at once placed himself at our command ... although from his numerous public engagements, his attendance here has not been so frequent as he and ourselves would have desired ... ${ }^{44}$

For the QMC, amateur science did not equate to a lack of expertise - in neither natural history, microscopy, illustration, engraving nor publishing. Rather, 'amateur' was used as a term to distinguish the society from what they felt was pernicious about the so-called 'professional societies' such as the RMS. An amateur for the QMC was anyone who considered himself or herself a microscopist and could afford the five-shilling annual fee. This was in opposition to the RMS, where new members needed to be nominated by existing members - and their scientific credibility validated-before acceptance. The club - and its aim of open membership - proved fruitful, and by the end of 1865 , there were seventy-three members, a number which would grow in the ensuing years. ${ }^{45}$

The QMC established itself as a monthly society where members could gather to discuss new microscopic technologies, exchange slides, present new findings and engage in discourse with fellow microscopists. The tone of the meetings was both scientific and colloquial - and, to this end, the QMC launched a second set of monthly meetings during its first year of existence called 'Science Gossips'. Invoking the name of the periodical from which the QMC was first established was intentional, and points to overlap between these two community sites; the public meeting and the publication of a periodical were seen as part of a connected practice.

These meetings were open to the public and their structure followed closely that of an exhibition of interesting objects and technologies, rather than explications of new findings of scientific merit. Both the Science Gossips and the regular meetings performed the function that a periodical would do for other societies - it allowed for the free and open communication of information among a specialized knowledge community.

44 Quekett Microscopical Club, Committee Book, clo the Natural History Museum, London, vol. 1, 17 July 1866, p. 031.

45 In fact, the Quekett Microscopical Society is one of the longest-running amateur societies, and is still operating as of 2018. 
Moreover - as the explicit adoption of Science Gossip's name indicates - the QMC meetings were, as Taylor explained in his preface, cited earlier, about 'uniting in monthly fellowship the unassuming but ardent lovers of nature'. ${ }^{46}$

For the first two years of its existence, the QMC maintained its open, colloquial and interpersonal nature. However, by 1867, monthly meetings were no longer enough for some members. These QMC members argued the society was in great need of a journal of its own. Unsurprisingly, the main promoter behind the establishment of the QMJ was Cooke. In January of 1867, he wrote a letter to the Quekett Committee arguing that it 'would be greatly to the advantage of the club to possess a recognized organ in which the papers read at the club and its proceedings would be chronicled either in full or copious abstract'. ${ }^{47}$ The remainder of the letter contained a description of how the journal should operate - as a free benefit to all members - and detailed how it should be structured. In particular, Cooke was keen to emphasize what the QMJ would not be. 'It is not intended to include notices of Exchanges, answers to correspondents or short communications, paragraphs of the character for which "Science Gossip" is especially designed' ${ }^{48}$ Here Cooke was referring to both the Science Gossip meetings and the structure of the periodical he edited. Unsurprisingly, Cooke offered his services as editor of the QMJ with the support of Hardwicke as the publisher. Indeed, Hardwicke, who was present at the meeting where Cooke's letter was read, even offered space within Science Gossip for the QMC as an alternative to the establishment of a separate and distinct journal. ${ }^{49}$

Communities, however, do not always function entirely harmoniously - especially when their younger members are looking to establish their own source of scientific and cultural recognition. After deliberation, the QMC committee decided that having Cooke as the sole editor - with full control over what was included and how the journal was to be structured - would not be beneficial to the society. Indeed, they were particularly worried that giving Cooke control over the journal would reduce, if not completely eliminate, the QMC's influence over the content of the journal. ${ }^{50}$

Eventually, the committee decided to publish its own journal - mostly under their members' own steam - but with Hardwicke as their publisher. They chose to run the journal through an editorial subcommittee, with W. Hislop as the first editorial chair, and John Bockett, S. Highley and Henry F. Hailes forming the remainder of the editorial team. The $Q M J$, at least in its first year, was supposed to be a journal run by a committee rather than through the dictate of a single individual. This communal ideal, however, quickly faltered; within a year Hislop retired without reason from the QMJ and it was decided that Hailes would take over as sole editor of the journal. ${ }^{51}$ Community, it seems, also had its limitations.

46 Taylor, op. cit. (23).

47 Quekett Microscopical Club, Committee Book, c/o the Natural History Museum, London, vol. 1, 25 January 1867, p. 51.

48 Quekett Microscopical Club, op. cit. (47), p. 58, underlining in original.

49 Quekett Microscopical Club, op. cit. (47), p. 58.

50 Quekett Microscopical Club, Committee Book, c/o the Natural History Museum, London, vol. 1, 27 February 1867, pp. 74-75.

51 English, op. cit. (19), p. 130. 
Once the initial questions of editorial control were established, and the QMJ started its print run, reservations about the publication remained within the community. In the month following the first issue of the $Q M J$, a letter was published in the medical periodical The Lancet, openly criticizing the QMC's need for a journal. In this letter, unnamed members of the QMC lamented the fact that the society had felt it necessary to make concrete through the printed page that which they felt was the best part of QMC meetings: their colloquial and informal nature. Rather than producing a journal, these rebel members argued,

If the Quekett Club will only carry out its original intention, of making its meetings partake more of the nature of a 'science gossip', it will continue one of the most popular Societies of the day; but we have little hesitation in taking an adverse view of matters if it seeks to run in the same groove [publishing a journal] as its Royal superior. ${ }^{52}$

For some QMC members, what it meant to be amateurs was to be the opposite of their 'Royal superior', the Royal Microscopical Society. In other words, they wished to keep meetings casual, and printing a journal represented the very opposite of such informal communication. This controversy over the establishment of a society journal indicates that there was no clear notion of what a journal was meant to do, nor of how it would differ from in-person meetings.

Despite the squabbles over who should edit the journal and whether it would change the nature of the society, the QMJ quickly established itself as a successful specialist journal. However, unlike Science Gossip, the use of illustrations was not central to the QMJ. In fact, when the QMC committee first stated what the journal would look like, they had this to say about images:

The projectors [of the $Q M J]$ cannot pledge themselves to illustrations. It is their desire to furnish two page plates per number, to illustrate papers read at the Club. They are willing to provide paper and pay for the printing if members who desire to have their papers illustrated will draw or have them drawn upon the stones for Lithography.

Unlike Science Gossip, which regularly employed Ruffle to engrave authors' drawings, the QMJ placed the responsibility on contributors to supply not only their own images, but also engravings of those images. The primary reason that the $Q M J$ limited the number of images was that - while Science Gossip operated as a purely commercial journal - the QMJ was given freely to members of the society, and only sold issues to non-members. Authors of articles, however, could pay for their own images to be reproduced. While this put the financial onus on the author rather than the journal, as we will see it also gave authors greater control over the credibility of their visual evidence.

During the first ten years of the QMJ's existence (1867-1877), the journal published a total of 4,367 articles, of which only fifty-nine were illustrated. Considering that the QMJ was structured very differently to both Science Gossip and the Midland Naturalist, it is worth taking a moment to deconstruct the type of article that was illustrated in the QMJ. While the specific content of Science Gossip and the Midland Naturalist may have varied significantly, the general structure of both periodicals

52 'The journal of the Quekett Club', The Lancet (4 January 1868) 2314, p. 32. 
included half of each issue being dedicated to new articles. The remainder operated as a space for readers to ask questions of the editor and fellow readers and have those questions answered in following issues. The QMJ, on the other hand, while also dedicating the first half of the journal to new articles, devoted the remainder to reports from meetings - and every fourth issue included the annual address from the president. For Science Gossip and the Midland Naturalist, images were regularly reproduced in both the first and second sections of each issue, whereas the QMJ almost never reproduced images in the meetings section. The distribution of images across these pages thus differs from that of Science Gossip or the Midland Naturalist. Furthermore, an examination of the distribution of illustrated articles appearing in the $Q M J$ within the same period of time also tells a different story. While meeting minutes were almost never illustrated, over a third of all original articles included illustrations. Over the ten-year period, these sixty-three illustrated articles accounted for ninety-nine plates reproducing 668 individual illustrations - all drawn and reproduced at the cost of the authors.

It is notable that the authorship of all these illustrations and illustrated articles was contained within a small community. Twenty-four authors contributed only one illustrated article each, with typically fewer than ten illustrations accompanying each of these. The remainder of the illustrated articles were written by a group of nine authors, each of whom wrote two or more articles. By far the most prolific illustrator for the QMJ was Cooke, publishing eight individual articles with 137 individual illustrations. Apparently the controversy over Cooke's offer to edit and run the QMJ did not deter either Hislop or Hailes from giving considerable space to Cooke for his microscopical work - so long as Cooke was willing to pay for the images himself.

Yet to analyse the value given to illustrations within a journal such as the QMJ requires looking beyond the authors who were given most space to reproduce their illustrations. Rather, examining the organization of images within the pages of the QMJ reveals that dominant members of the community - such as Cooke - were not automatically given a privileged position for their illustrations within the journal. This is evident upon further investigation of an image by one of the most infrequent authors of the QMJ.

Benjamin Thomson Lowne was a member of the Royal College of Surgeons, which allowed him to practise medicine in Great Britain. Other than this qualification and his interest in microscopy, he was not a published book author, nor did he regularly contribute to any other periodicals. His sole article for the $Q M J$ related to his microscopical investigation of the of the proboscis of a fly. ${ }^{53}$ The article included one lithograph showing simultaneously the internal and external structure of a blowfly's mouth (Figure 7). While this image was the ninth plate in the first volume of the journal, when it came to binding the journal at the end of the year, the plate was removed from its article and placed as the frontispiece to the whole volume. This gave Figure 7 priority of place over all other illustrations in the volume, including Cooke's.

Closer examination of both the illustration and what Lowne said about it reveals a complicated relationship between the authorship of the image and the values of

53 B.T. Lowne, 'On the proboscis of the fly', Quekett Microscopical Journal (1867) 1(5), pp. 126-132. 


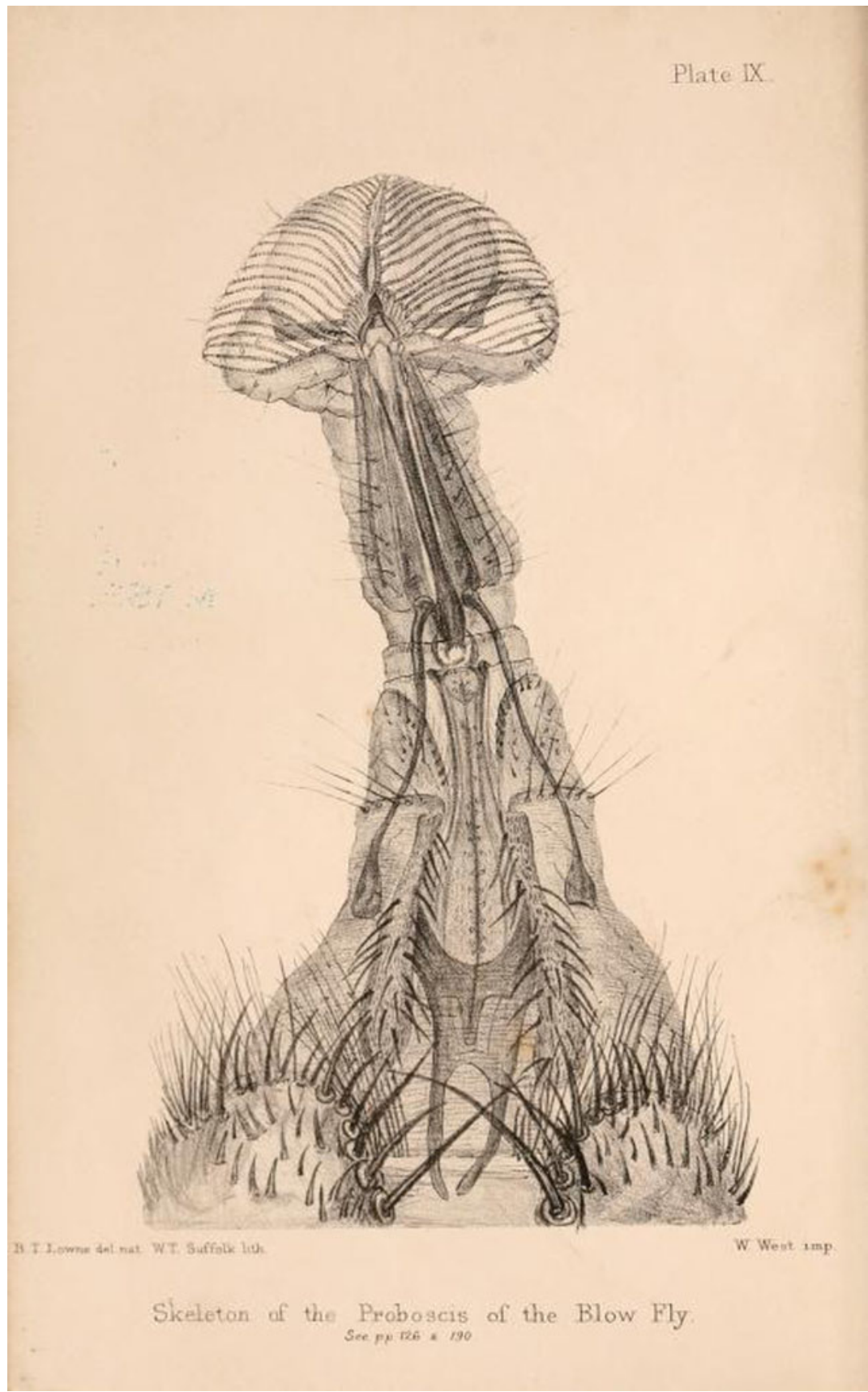

Figure 7. Frontispiece for volume 1 of the $Q M J$ entitled 'Skeleton of the proboscis of the blow-fly', a lithographic print drawn by B.T. Lowne, lithographed by W.T. Suffolk and printed by W. West. Journal of the Quekett Microscopical Club (NNNN) 1(1), frontispiece. Image from the Biodiversity Heritage Library at www.biodiversitylibrary.org/item/18828\#page/6/mode/1up. 
observational verisimilitude ascribed to drawing. Located at the bottom of the illustration are three names - Lowne's own, as the delineator; W.T. Suffolk, as the lithographer; and W. West, as the printer. While Lowne had only recently joined the QMC before publishing his article, Suffolk had been a member since 1866 and would also give a series of important lectures to the society on Microscopical Manipulations in 1870. West had been a member of the QMC since 1865. Thus the inclusion of three active members of the QMC at the bottom of the image means it was not just the fly's proboscis on display, but also the community that made this image possible. In essence, the specific expertise of individual society members was brought together to create both specific illustrations and the journal as a whole.

Yet even if the image was produced by communal effort, it was not without its problems. Immediately following the frontispiece was a description of the plate - bound on a separate piece of paper - which reads,

[The plate] Represents the dorsal aspect of the fly's proboscis, mounted in balsam without pressure, magnified about 40 diameters, and it is intended to shew the relations of the several parts. The lips are more inflated than is natural during life, a result which cannot be avoided in preparations like that from which the accompanying plate is taken. ${ }^{54}$

Lowne wanted to ensure that his readers did not assume that this was a perfect visual interpretation of the proboscis of a blowfly. Rather, he wanted them to know that in order to interpret the image, one needed to understand that the very process of preparing a microscope slide changed how a subject looked when visualized. With this description, Lowne was assuming that not all QMJ readers had the expertise to interpret this image without description. It was, however, through the very reproduction of images such as Figure 7 and the accompanying textual descriptions that the knowledge and expertise of each individual member was made available and accessible to the whole community. This, at least for the QMC, was what it meant to publish a society journal.

\section{The Midland Naturalist}

Three years after Hardwicke's death in 1875, the Midland Naturalist was established under the auspices of Hardwicke's publishing house. The periodical was intended to act as a communication hub for a set of naturalist societies operating in British cities and towns in the triangle between Birmingham, Nottingham and Northampton. The Midland Naturalist was a culmination of the differing communities and formats established by Science Gossip and the QMC: it encapsulated all forms of natural history, but was built for a group of established audiences. The entire premise of the journal was to act as a site for facilitating communication among the societies' members, and to disseminate new discoveries and information more quickly. The journal editors, E.W. Badger and W.J. Harrison, after lamenting the small number of members who had subscribed to the journal in its first year, understood that the journal's success would hinge on whether they could include illustrated articles, on both popular and 'abstruse' scientific

54 Lowne, op. cit. (53), 'Description of Plate IX. - (Frontispiece)', located between frontispiece and front matter. 
topics. ${ }^{55}$ They also understood that, first and foremost, they needed subscribers in order to fund illustrations. Unlike the QMJ, the Midland Naturalist was not offered as a free benefit to society members - rather the members of the consortium of societies which made up the base of the journal would act as primary subscription targets.

The importance of images to the Midland Naturalist - for both readers and authors was made clear within five months of the journal being established. In the fifth issue of the first volume, the botanist William Bywater Grove wrote a promotional article for Alfred Pumphrey's new 'autographic' process for printing drawings. ${ }^{56}$ The process involved the use of chemical photographic techniques to reproduce direct copies of drawings made with ink on paper. ${ }^{57}$ As Grove explained to readers of the Midland Naturalist,

The Autographic process is superior to lithography in the delicacy of its results ... It is especially applicable to cases where only a limited number of copies is required, as for circulars, examination papers, music \&c., which can be printed at home, but, above all for securing a record of any original microscopical or other observation; the drawing can be made without any elaborate preparation, and the absolute fidelity of the copies ensured. ${ }^{58}$

For Grove, the essential benefit of Pumphrey's technology was that it allowed for 'absolute fidelity' in the reproduction of the images. For a naturalist like Grove, this meant that society members who were hoping to communicate new discoveries they had made - whether microscopical or otherwise - could trust the journal to maintain the fidelity of their observations; and, moreover, that good natural history relied on good observation, which in turn necessitated the production and reproduction of images.

To prove this point, Grove included eight plates made using Pumphrey's method. The first of these accompanied an article written by Grove discussing the hybridity of ferns (Figure 8). ${ }^{59}$ This article was written in response to an earlier piece by Edward Joseph Lowe (1825-1900), a respected botanist, meteorologist and astronomer who was a fellow of the Royal Society and the Linnaean Society. ${ }^{60}$ Lowe's article, which was not illustrated, was on 'abnormal ferns' and described how two species of the same genus could, on rare occasions, produce a hybrid form. The point of this article was to give further evidence in support of Charles Darwin's theory of plant evolution.

As Grove saw it, however, this was a contestable point which required visual validation. Hence the need for three images - printed with 'absolute fidelity' - to demonstrate how two individual plants might become hybridized. Images, and the reliability of printing technologies, were an essential aspect in making a claim in support of a controversial

55 'Preface', Midland Naturalist (1878) 1, n.p.

56 W.B. Grove, 'The autographic process', Midland Naturalist (1878) 1(5), pp. 132-133.

57 Grove describes Pumphrey's autographic process as follows: gelatine was applied to a lithographic stone, a solution of bichromate of potash was washed over the top, the drawing was applied to the prepared stone facing down. Where ink touched the stone, the gelatine would become raised, creating a relief surface, which would then have ink applied, and prints were made from the stone. Grove, op. cit. (56), p. 132.

58 Grove, op. cit. (56), p. 133.

59 W.B. Grove, 'A hybrid fern', Midland Naturalist (1878) 1(2), pp. 52-53.

60 Ray Desmond, Dictionary of British and Irish Botanists and Horticulturists: Including Plant Collectors, Flower Painters, and Garden Designers, London: Taylor \& Francis, 1994, p. 439. 


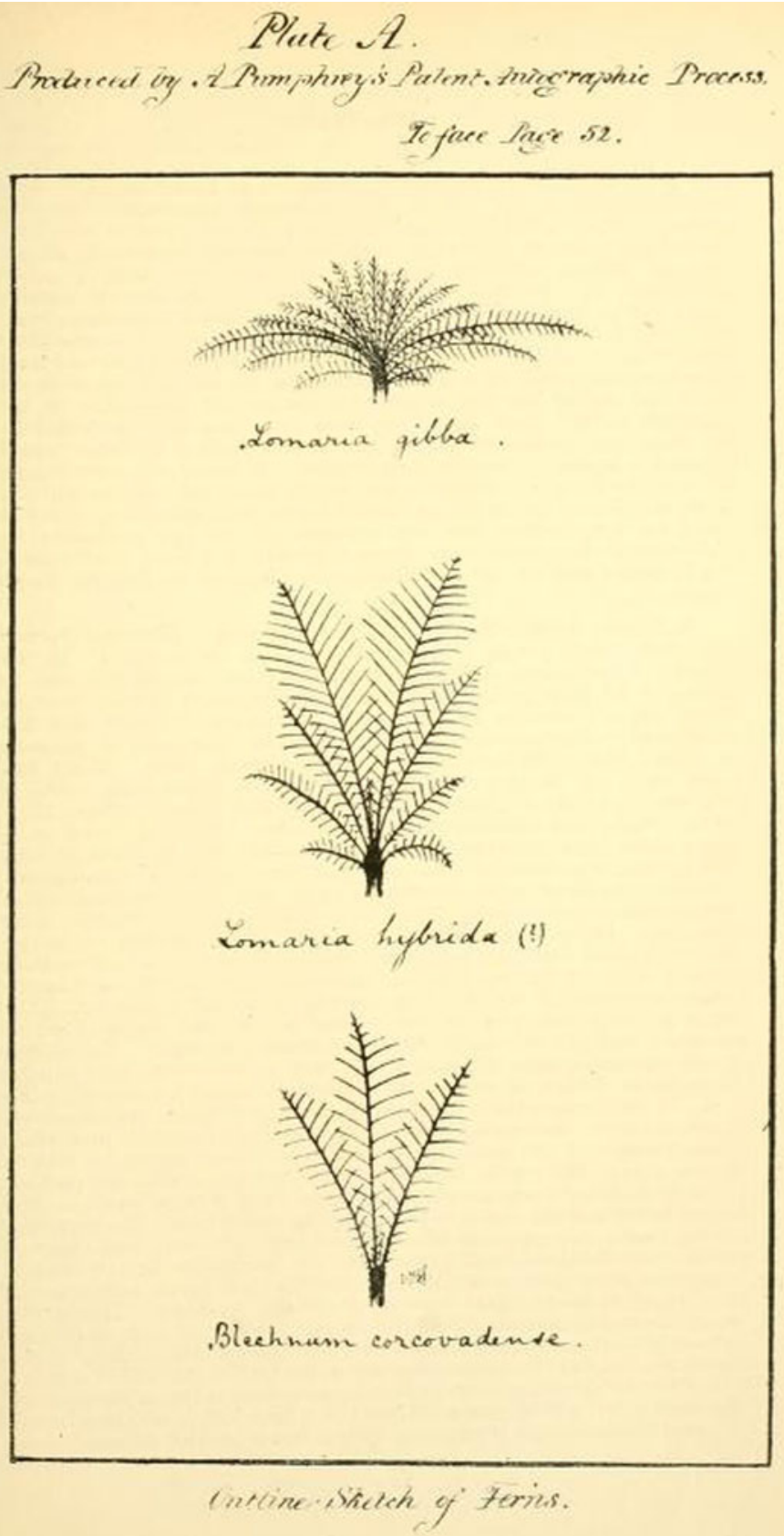

Figure 8. Plate A from W.B. Grove's article 'A hybrid fern' in the Midland Naturalist, reproduced using Alfred Pumphrey's 'autographic' printing process. Midland Naturalist (1878) 1(2), pp. 52-53. Image from the Biodiversity Heritage Library at www.biodiversitylibrary.org/item/50180\#page/71/ mode/1up. 
subject. At the same time, however, images could not act alone. Before these two articles and their accompanying illustrations reached the pages of the Midland Naturalist, they first had to be discussed in person. Lowe's original article was read first on 11 December, at the Birmingham Natural History Society meeting. ${ }^{61}$ Grove therefore relied also on the importance of physical meetings to validate his evidence. At the end of his article, Grove referred to the successful hybridization of two similar species of fern by 'a well-known fern-grower' which had been displayed at the Royal Horticultural Society six years previously. While the hybrid example had since been lost, 'the correctness of his explanation [of the hybrid] was, of course, disputed at the time ... this independent production of what is nearly the same species seems to confirm it strongly'. ${ }^{62}$

Grove believed that in order for the Midland Naturalist to produce reliable information there needed to be a mixture of text, images and verbal evidence, as well as opportunities for the community that made up the periodical's readership to hear, read and see the evidence at hand. This was made explicit with the remainder of the seven plates Grove reproduced for his article on Pumphrey's autographic process. The choice of what would be illustrated to prove Pumphrey's process was left up to the attendees of the Birmingham Natural History and Microscopical Society. At the meeting on 2 April 1878, society members presented Pumphrey with their own sketches, whereupon he immediately produced copies using his process. ${ }^{63}$ This performance was then extended to the Midland Naturalist by the reproduction of a selection of these sketches. As such, this article became not just a description of how images could be made reliable within a journal, but also an enacted performance, involving the journal, the society, the members of the society and Pumphrey.

Harrison's lament over the number of illustrations and readers of the Midland Naturalist in its first year - cited earlier - seems to have gone unheeded. Despite the invocation from Grove for authors to utilize illustrations in their articles, there was little change to the number of illustrations in the Midland Naturalist in its second year of publication. Whereas volume 1 included nineteen plates and seventy-seven individual images across twelve issues, volume 2 only included ten plates and sixty-three images. It is noteworthy that, following the appearance of Grove's article, Pumphrey's method was not used again. This indicates that, despite the best efforts of authors such as Grove, new image-making technologies were not always adopted by editors or authors.

\section{Conclusion}

Observing, talking, writing, drawing, engraving and printing were intertwined and codependent practices in nineteenth-century natural history. And they were all practices that were made and remade through collaboration and community debate. Images, in this article, have acted as representative objects for investigating these co-dependent practices.

61 See E.J. Lowe, 'Abnormal ferns', Midland Naturalist (1878) 1(1), pp. 5-8, 5.

62 Grove, op. cit. (59), p. 53.

63 Grove, op. cit. (56), pp. 132-133. 


\section{2}

The article has followed a group of individuals as they moved across the seemingly firm boundaries of various sites of scientific communication: the society meeting, pen and paper, woodblock or lithographic plate, and the periodical page. The actors in the article - Robert Hardwicke, Mordecai Cubitt Cooke, Worthington George Smith and George Ruffle - formed the core of the analysis, but they were just one community among many in the production of natural history in the period.

As this article has demonstrated, periodicals like Science Gossip, QMJ, and the Midland Naturalist were established to 'unit[e] in monthly fellowship the unassuming but ardent lovers of nature'. ${ }^{64}$ This community language borrowed from the terminology of the professional division - whether specifically adopting the label of 'amateurs' or by defining the community as 'unassuming'.

Images, moreover, as this article has shown in the frontispiece of Science Gossip (Figure 4), could be utilized to reinforce notions of imagined national scientific communities. Images, communities and ideologies became intertwined in the publication of periodicals. Moreover, the analysis in this article has shown that in order to investigate the range of participants and practices of participation in nineteenth-century science, research must incorporate both the textual and the visual, and that practices must be traced across the range of community sites in which they were developed and enacted.

64 Taylor, op. cit. (23), preface. 